\title{
Effects of various chemical decontaminants on Salmonella Typhimurium survival in chicken carcasses
}

\author{
Okan AGIRDEMIR ${ }^{1}$, Ozen YURDAKUL ${ }^{1}$, Erhan KEYVAN ${ }^{1 *}$ (D), Erdi SEN ${ }^{1}$
}

\begin{abstract}
Salmonella Typhimurium is one of the most common foodborne pathogens isolated from poultry meat. The goal of this study was to investigate $S$. Typhimurium survival in broiler carcasses exposed to ozone, lactic acid, sodium hypochlorite and levulinic acid. $S$. Typhimurium was inoculated into broiler carcasses, which were divided into eight treatment groups, including a positive and negative control group. After standardized bacterial culture methods, microbiological analysis revealed a statistically significant relationship between the number of bacteria detected and the concentration and application time in all the treatment groups $(p<0.05)$. As compared with the control group, all the treatments were effective in terms of inactivation of $S$. Typhimurium. There was a significant decrease in the $1.5 \mathrm{ppm}$ ozone treatment group ( $5 \mathrm{~min}$ and $15 \mathrm{~min}$ ) as compared with that in the other chemical decontaminant groups $(p<0.05)$. However, there was no significant difference in reduction of $S$. Typhimurium among the other treatment groups, irrespective of the treatment time $(p>0.05)$. Among the decontaminants, the most effective chemical solution was 3\% LEV. The ozone treatment caused a lower logarithmic decrease in S. Typhimurium numbers at all treatment times as compared with that in the other treatment groups.
\end{abstract}

Keywords: lactic acid; levulinic acid; ozone, Salmonella Typhimurium; sodium hypochlorite.

Practical Application: Determining effective decontaminants and appropriate concentrations with application times on Salmonella Typhimurium in chicken carcasses.

\section{Introduction}

Meat derived from animals is an important source of nutrients in the human diet (Pereira \& Vicente, 2013). Poultry meat is an important source of protein, essential polyunsaturated fatty acids, and other dietary components, such as vitamins and minerals (Givens et al., 2006; Barroeta, 2007; Farrell, 2013). Poultry meat consumption is increasing in many developed countries, with chicken meat the most commonly consumed products, followed by turkey meat (Rouger et al., 2017; Wang et al., 2018). Contamination of chicken carcasses with Salmonella spp., Listeria monocytogenes, and Campylobacter spp. may occur at various stages of processing in poultry processing plants (Goncuoglu et al., 2016; Zhu et al., 2017; Oliveira et al., 2018). These foodborne pathogens can cause life-threatening infections in humans (van Nierop et al., 2005; Cetin et al., 2019).

Foodborne pathogens are a major concern and represent a public health problem worldwide (Manoj et al., 2015; Sánchez-Gamboa et al., 2018; Chavez-Martinez et al., 2019; Cruz et al., 2019; Yang et al., 2020). Salmonella spp. are one of the most commonly isolated pathogens from foods of animal origin (Heredia \& García, 2018; Mendonça et al., 2019; Cunha-Neto et al., 2019). An earlier study estimated that 93.8 million foodborne illnesses occurred annually worldwide and that 155,000 humans worldwide died annually from salmonellosis (Eng et al., 2015). Salmonella serotypes are the most important pathogens in chicken meat (Antunes et al., 2016; Zwe et al., 2018). Previous studies reported a high prevalence of Salmonella spp. and Salmonella
Typhimurium (S. Typhimurium) in chicken meat (Yang et al., 2010; Freitas et al., 2010; El-Aziz, 2013; Abd-Elghany et al., 2015; Thung et al., 2016; Ren et al., 2017; Trongjit et al., 2017; Xu et al., 2018; Sharma et al., 2019; Jia et al., 2020). Mani-López et al. (2012) reported that $S$. Typhimurium was the most widespread serotype associated with foodborne infections.

Chicken carcasses and their components are often contaminated with spoilage bacteria because of excessive carcass manipulation, including stunning, scalding in a water bath, feather removal, and chilling, in processing plants (Rouger et al., 2017). Various methods are used to reduce microorganism contamination in chicken carcasses and meats during processing (Del Río et al., 2007). These include chemical methods (organic acids, phosphates, acid-phosphate mixtures), physical methods (ionizing radiation, pulsed X-rays, steam, or hot water dips/sprays), electromagnetic waves (ultraviolet light and microwaves), high-intensity pulsed electric fields, oscillating magnetic fields, and natural antimicrobials (Pothakamury et al., 1993; Lillard,1994; Zhang et al., 1994; Dorsa et al., 1996; Bautista et al., 1997; Farkas, 1998; Sofos \& Smith, 1998; Barbosa-Canovas et al., 2000; Sastry et al., 2000; Datta \& Davidson, 2000; Huffman, 2002; Portela et al., 2019). The objective of the present study was to determine the survival of $S$. Typhimurium in broiler carcasses treated with different concentrations of ozone, lactic acid (LA), sodium hypochlorite ( $\mathrm{NaClO}$ ), and levulinic acid (LEV) applied for different times. 


\section{Material and methods}

\subsection{Bacterial strain}

S. Typhimurium ATCC 14028 was used for contamination of chicken carcasses. Cultures were grown overnight in tryptic soy broth broth (Oxoid, England) culture at $37^{\circ} \mathrm{C}$. The culture was adjusted to a $0.5 \mathrm{McF}$ arland turbidity standard (approximately $10^{8} \mathrm{cfu} / \mathrm{mL}^{-1}$ ). Chicken carcasses were then contaminated with standardized bacterial culture for the experiments (Durak et al., 2012).

\subsection{Application of the decontaminants}

The chicken carcasses $(n=144)$ were obtained from local producers in Burdur Province, Turkey. All the chicken carcasses $(1.2-1.4 \mathrm{~kg})$ were quickly taken to the laboratory under cold-chain conditions. There were eight treatment groups, including a negative and positive control group. The treatment groups were as follows: LA (90\%) (Merck, Germany), 30 ppm NaClO (Tekkim, Turkey), and $2 \%, 2.5 \%$, and $3 \%$ LEV (99\%) (Sigma-Aldrich, USA), with each treatment applied for 5, 10, and $15 \mathrm{~min}$. Post-treatment, the samples were stored at $4^{\circ} \mathrm{C}$. The groups were examined 0,3 , and $7 \mathrm{~d}$ post-treatment to determine the effects of the storage conditions on chicken carcasses. The experimental design of the study is shown in Figure 1. An ozone generator (Genozon, GN-Q1005S, Turkey) was used to standardize the ozone level (1.5 ppm) in the decontaminant solution.

\subsection{Microbiological analysis}

Microbiological analysis of $S$. Typhimurium in the decontaminated chicken carcasses at the different application times was analyzed using conventional culture methods.

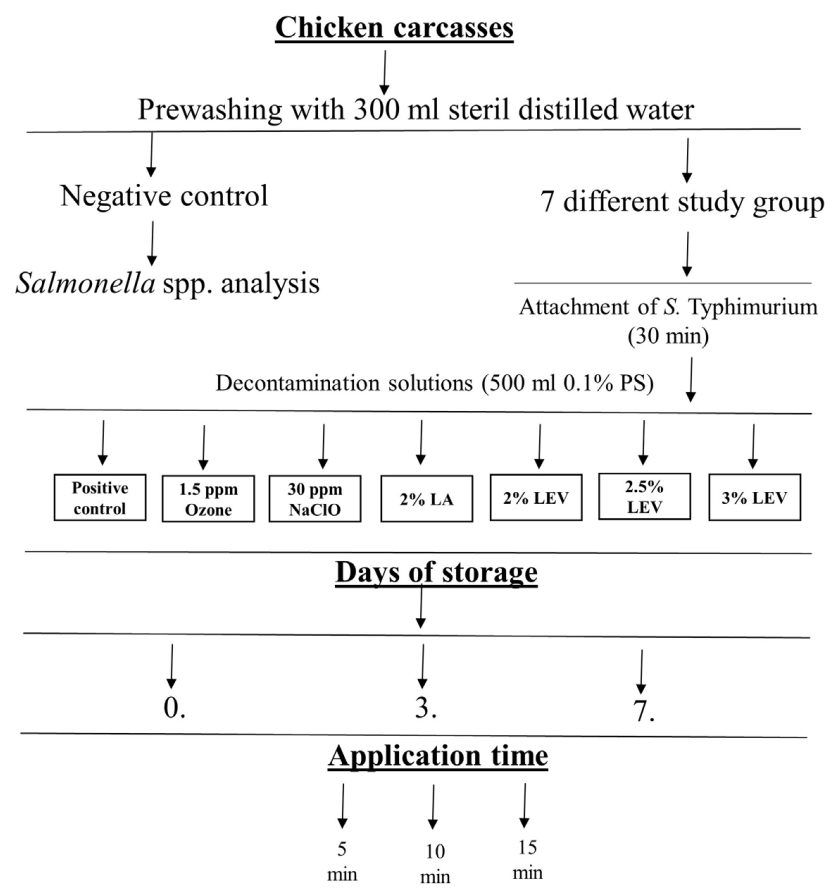

Figure 1. Decontamination of chicken carcasses with the chemical decontaminants. $\mathrm{NaClO}$ : sodium hypochlorite, LA: lactic acid, LEV: levulinic acid.
For this purpose, freshly processed broiler carcasses were rinsed, and the rinses were serially diluted 10 -fold with $0.1 \%$ peptone water (Oxoid, England). The samples were then spread on xylose lysine deoxycholate agar (Merck) and brilliant-green phenol-red lactose sucrose agar (Merck). Colonies were inoculated into triple sugar iron (Merck) agar and lysine iron agar (Merck). The isolates were then tested with Salmonella antiserum (Difco 2264-47-2) (Mulder et al., 1987; Andrews et al., 2019).

\subsection{Statistical analysis}

The SPSS software package (version 25.0 for Windows) was used for statistical analysis. The appropriateness of the data to an analysis of variance in the factorial order was evaluated by a multivariate normal distribution and homogeneity of Box-M variance test. A factorial analysis of variance was used to compare the means. If the parametric (variance analysis in factorial order) did not meet the prerequisites, the data were recovered by Box-Cox data transformation, and the variance analysis in the factorial order was used with the transformed data obtained. Multiple comparisons were averaged according to Fisher's least significant difference method. The significance level was accepted as $p<0.01$ and $p<0.05$.

\section{Results}

\subsection{Control group}

In the positive control group, $6.60 \log \mathrm{cfu} / \mathrm{mL}$ was detected on $\mathrm{d} 0,6.81 \log \mathrm{cfu} / \mathrm{mL}$ was detected on $\mathrm{d} 3$, and $6.88 \log \mathrm{cfu} / \mathrm{mL}$ was detected on $\mathrm{d} 7$.

\subsection{Inactivation of S. Typhimurium by ozone}

In this study, as compared with the control group, the application of ozone for 5 min reduced the levels of $S$. Typhimurium, with $1.21,1.51$, and $1.57 \log \mathrm{cfu} / \mathrm{mL}$ recorded on $\mathrm{d} 0,3$, and 7 , respectively. In the 10 -min treatment group, the $S$. Typhimurium counts on $\mathrm{d} 0,3$, and 7 were reduced to $1.43,1.77$, and $1.88 \log \mathrm{cfu} / \mathrm{mL}$, respectively. The application of ozone for $15 \mathrm{~min}$ decreased the levels of $S$. Typhimurium to $1.13 \log \mathrm{cfu} / \mathrm{mL}, 1.21 \log \mathrm{cfu} / \mathrm{mL}$, and $1.47 \log \mathrm{cfu} / \mathrm{mL}$ on $\mathrm{d} 0,3$, and 7 , respectively. When the effect of the ozone application on $S$. Typhimurium survival was examined, the most effective treatment time was $10 \mathrm{~min}$ (Figure 2). There was also a statistically significant difference in the 5-min treatment group after 0,3 , and $7 \mathrm{~d}$ as compared with that in the 15-min treatment group on the same days. $(p<0.05)$.

\subsection{Inactivation of S. Typhimurium by LA}

Table 1 and Figure 3 show the reduction in the levels of S. Typhimurium following the application of $2 \%$ LA for 5,10 , and $15 \mathrm{~min}$ as compared with those in the positive control. 


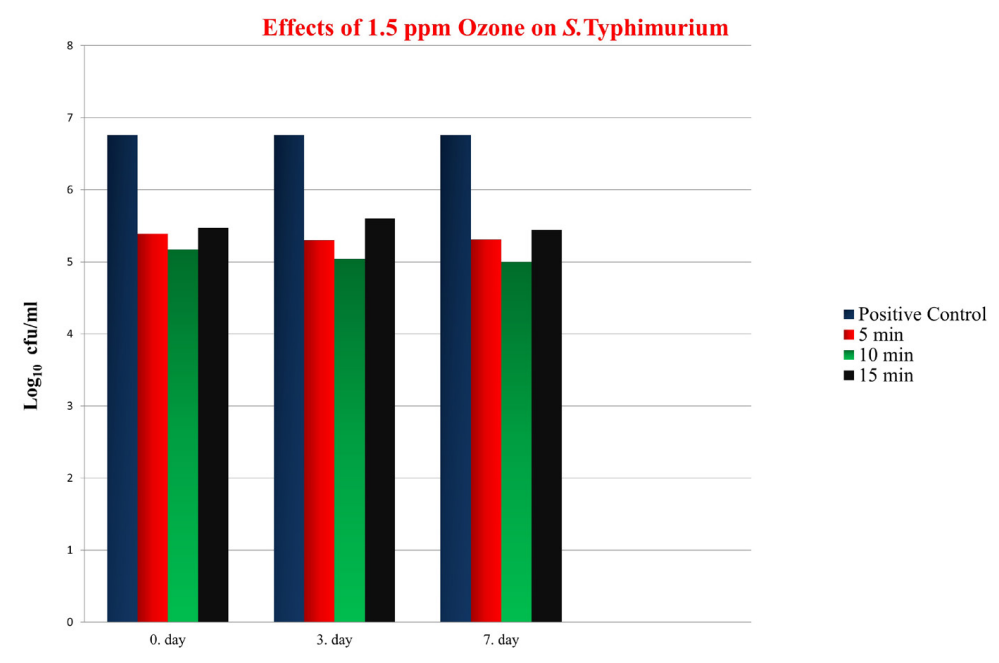

Figure 2. Effects of the $1.5 \mathrm{ppm}$ ozone treatment on $S$. Typhimurium survival.

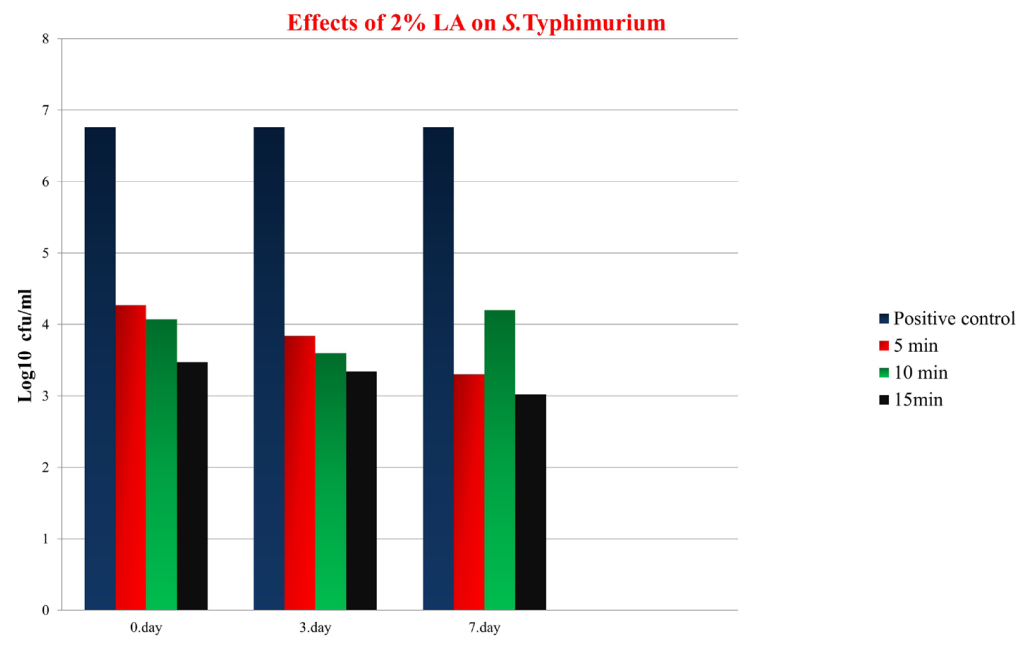

Figure 3. Effects of 2\% LA on S. Typhimurium survival. LA: Lactic acid.

Table 1. Reduction in the levels of $S$. Typhimurium in the group treated with $2 \%$ LA.

\begin{tabular}{|c|c|c|c|c|c|c|c|c|c|}
\hline & \multicolumn{9}{|c|}{ Reduction Level (log cfu/mL) } \\
\hline & \multicolumn{3}{|c|}{$5 \mathrm{~min}$} & \multicolumn{3}{|c|}{$10 \min$} & \multicolumn{3}{|c|}{$15 \mathrm{~min}$} \\
\hline \multirow{2}{*}{$2 \% \mathrm{LA}$} & 0. day & 3. day & 7. day & 0. day & 3. day & 7. day & 0. day & 3. day & 7. day \\
\hline & 2.33 & 2.97 & 3.58 & 2.53 & 3.21 & 2.68 & 3.13 & 3.47 & 3.86 \\
\hline
\end{tabular}

Table 2. Reduction in the levels of $S$. Typhimurium in the group treated with 2\%, 2.5\%, and 3\% LEV.

\begin{tabular}{|c|c|c|c|c|c|c|c|c|c|}
\hline \multirow{3}{*}{ Concentration of LEV } & \multicolumn{9}{|c|}{ Reduction Level (log cfu/mL) } \\
\hline & \multicolumn{3}{|c|}{$5 \mathrm{~min}$} & \multicolumn{3}{|c|}{$10 \mathrm{~min}$} & \multicolumn{3}{|c|}{$15 \mathrm{~min}$} \\
\hline & 0. day & 3. day & 7. day & 0. day & 3. day & 7. day & 0. day & 3. day & 7. day \\
\hline $2 \%$ & 2.43 & 2.79 & 2.86 & $(-)$ & 3.21 & 2.82 & $(-)$ & $(-)$ & $(-)$ \\
\hline $2.5 \%$ & 2.79 & 2.77 & 2.58 & 3.43 & 3.42 & 3.41 & $(-)$ & $(-)$ & $(-)$ \\
\hline $3 \%$ & $(-)$ & $(-)$ & $(-)$ & $(-)$ & $(-)$ & $(-)$ & $(-)$ & $(-)$ & $(-)$ \\
\hline
\end{tabular}

(-): All the $S$. Typhimurium population was inactivated by LEV. LEV: levulinic acid.

\subsection{Inactivation of S. Typhimurium by $2 \%, 2.5 \%$, and $3 \%$ LEV}

Table 2 and Figure 4 show the reduction in the levels of S. Typhimurium after the $2 \%, 2.5 \%, 3 \%$ LEV applications for $5 \mathrm{~min}, 10 \mathrm{~min}$, and $15 \mathrm{~min}$, respectively, as compared with those in the positive control.

\subsection{Inactivation of S. Typhimurium by NaClO}

Table 3 and Figure 5 provide information on the reduction in the levels of $S$. Typhimurium in the $30 \mathrm{ppm} \mathrm{NaClO}$ application group after 5, 10, and $15 \mathrm{~min}$ as compared with those in the positive control. 
Table 3. Reduction in the level of $S$. Typhimurium in the $30 \mathrm{ppm} \mathrm{NaClO}$ group.

\begin{tabular}{|c|c|c|c|c|c|c|c|c|c|}
\hline \multirow{4}{*}{30 ppm NaClO } & \multicolumn{9}{|c|}{ Reduction Level (log cfu/mL) } \\
\hline & \multicolumn{3}{|c|}{$5 \mathrm{~min}$} & \multicolumn{3}{|c|}{$10 \mathrm{~min}$} & \multicolumn{3}{|c|}{$15 \mathrm{~min}$} \\
\hline & 0. day & 3. day & 7. day & 0. day & 3. day & 7. day & 0. day & 3. day & 7. day \\
\hline & 2.58 & 3.81 & 4.18 & 1.21 & 2.51 & 3.88 & 3.21 & $(-)$ & $(-)$ \\
\hline
\end{tabular}

(-): All the $S$. Typhimurium population was inactivated by the $\mathrm{NaClO}$ treatment. $\mathrm{NaClO}$ : sodium hypochlorite.
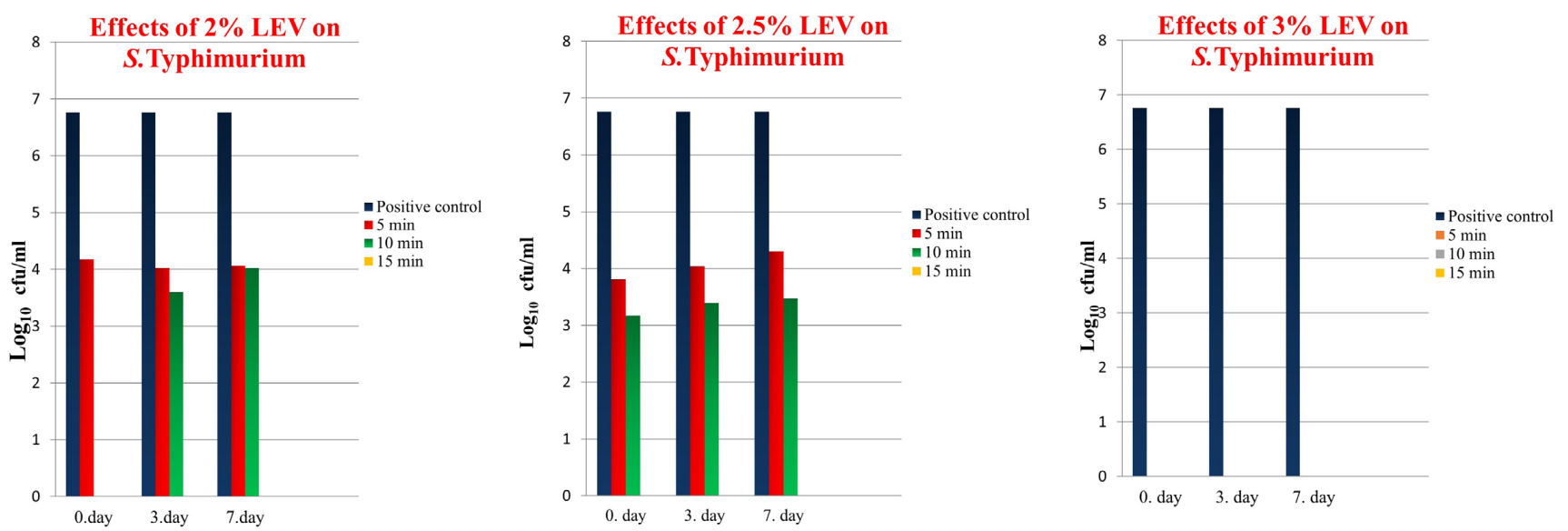

Figure 4. Effects of 2\%, 2.5\%, and 3\% LEV on S. Typhimurium counts. LEV: levulinic acid.

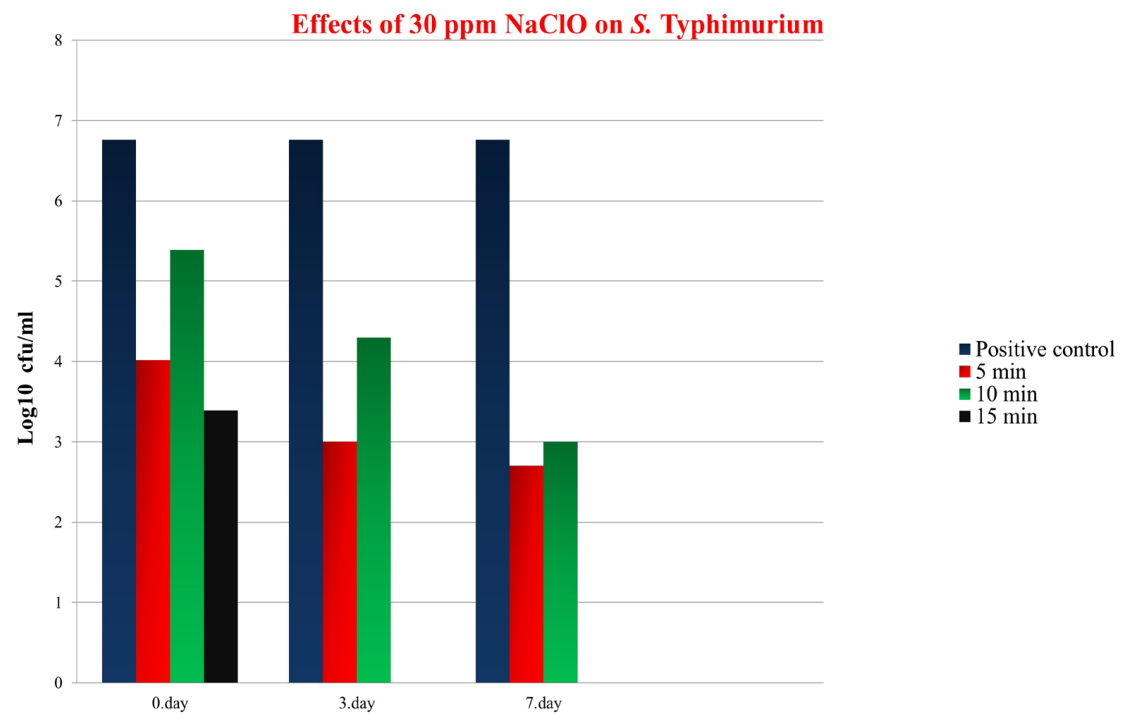

Figure 5. Effects of $30 \mathrm{ppm} \mathrm{NaClO}$ on $\mathrm{S}$. Typhimurium.

\section{Discussion}

Salmonella spp. are an important foodborne pathogen in the poultry industry. The occurrence of Salmonella spp. in animal products is indicative of flaws in poultry handling or mishandling of chicken carcasses during processing (Freitas et al., 2010). Abbassi-Ghozzi et al. (2012) reported the highest occurrence of Salmonella spp. (48.3\%) in chickens among different meat samples (beef, lamb meat, and minced meat). High levels Salmonella infection (salmonellosis) associated with chicken products have been reported in Brazil, Egypt, China, Malaysia, Thailand, and India (Freitas et al., 2010; Yang et al., 2010; El-Aziz,
2013; Abd-Elghany et al., 2015; Thung et al., 2016; Ren et al., 2017; Trongiit et al., 2017; Sharma et al., 2019). The findings indicate that contamination of chicken and broiler products with Salmonella spp. are common worldwide. For this reason, effective methods need to be developed to prevent contamination of chicken products with Salmonella spp. in poultry processing plants.

Various chemical agents and methods can be used for decontamination of chicken carcasses. LA is a harmless, cheap, and safe compound used in the decontamination of foods. LA is generally recognized as safe by the U.S. Food and Drug Administration 
for meat products (Mani-López et al., 2012). The effectiveness of organic acids, such as LA, against microorganisms depends on the concentration, exposure time, and temperature (Dickson \& Anderson, 1992). The effectiveness and antimicrobial effects of LA in poultry has been studied extensively. In one study, researchers observed a $2.2 \log \mathrm{cfu} / \mathrm{mL}$ reduction in $S$. Typhimurium following the application of $1 \%$ and $2 \%$ LA to chickens for $30 \mathrm{~s}$ at $20{ }^{\circ} \mathrm{C}$ (Xiong et al., 1998). Mohamed \& Abdel-Naeem (2018) found a $1 \log \mathrm{cfu} / \mathrm{cm}^{2}$ and $3.3 \log \mathrm{cfu} / \mathrm{cm}^{2}$ reduction in $S$. Typhimurium in chicken carcasses following the application of $1 \%$ and $2 \% \mathrm{LA}$, respectively. Other studies also reported that $1 \%$ LA was effective against $S$. Typhimurium (Slavik et al., 1997; Madushanka et al., 2018). The present study determined the effect of $2 \%$ LA against $S$. Typhimurium in chicken carcasses. The results pointed to similarities with the findings of the aforementioned studies, despite differences in concentrations and application times.

LEV is a permeable substance that allows the penetration of cells (Helander et al., 1997; Alakomi et al., 2000). There have been only a few studies on the effect of LEV on Salmonella spp. inactivation in broiler carcasses. Zhao et al. (2011) reported that LEV was effective in decontamination of Salmonella spp., reporting a $5 \log \mathrm{cfu} / \mathrm{cm}^{2}$ reduction in treated chicken carcasses. LEV was reported to be effective, even at low concentrations (Zhao et al., 2009). In our study, we found similar findings in terms of the decontamination effectiveness of LEV against $S$. Typhimurium in chicken carcasses. In the present study, the most effective concentration of $\operatorname{LEV}(2 \%, 2.5 \%$, and $3 \%)$ and application time $(5,10$, and $15 \mathrm{~min})$ was $3 \%$ and $15 \mathrm{~min}$, respectively (Figure 4). Differences in the application times and decontaminant concentration are likely the main reason for differences observed between our findings and the results of other studies.

The effect of ozone varies according to the $\mathrm{pH}$, temperature, humidity, presence of additives, and organic substances in the environment (Kim et al., 1999). The half-life of ozone in water is only $20-30 \mathrm{~min}$. In the present study, the ozone treatment was applied at room temperature $\left(20^{\circ} \mathrm{C}\right)$ because previous research demonstrated that it was most effective at this temperature (Guzel-Seydim et al., 2004). Cho et al. (2015) treated chicken breasts with ozone gas during cold storage for $3 \mathrm{~d}$. They reported a decrease of $0.79 \log \mathrm{cfu} / \mathrm{g}$ in the number of $S$. Typhimurium. In another study on chicken carcasses contaminated with $S$. Typhimurium and treated with ozone $(10 \mathrm{ppm})$ carcasses for $45 \mathrm{~min}$, the authors observed a $0.7 \log \mathrm{cfu} / \mathrm{mL}$ decrease (Fabrizio et al., 2002). Based on our results and those of other studies, the oxidation capacity of ozone in terms of decontamination appears to decrease with time.

Chlorine is a broad-spectrum decontamination agent. Hypochlorites have been shown to have antimicrobial activity against bacteria, bacterial spores, viruses, fungi, algae, and protozoa (Park et al., 2001). $\mathrm{NaClO}$ is a disinfectant widely used in the food industry due to its ease of use and low cost (Meireles et al., 2016; Park et al., 2016). Chlorine at a concentration 20-50 ppm is recommended because it causes an undesirable odor at higher concentrations in decontamination of food (Sofos \& Smith, 1998). Thus, in the present study, the $\mathrm{NaClO}$ concentration used was 30 ppm. Yang et al. (2001) reported a reduction of $1 \log$ unit in chicken skin inoculated with $S$. Typhimurium and treated with $50 \mathrm{ppm}$ chlorinated water for $50 \mathrm{~min}$. In other research, spraying chicken carcasses with $\mathrm{NaClO}$ (20-40 ppm) for $3.5 \mathrm{~s}$ reduced the number of $S$. Typhimurium from $90 \%$ to $96 \%$ (Bailey et al., 1986). Despite differences in decontamination methods and application times among the reported studies, the effectiveness of $\mathrm{NaClO}$ is similar to those in the literature.

\section{Conclusion}

Despite technological advances in poultry meat cutting lines, developments in logistics infrastructure, innovations in packaging technology, application of preservation methods, and consumer awareness, microorganism contamination of chicken products remains a problem. Decontamination processes in poultry slaughterhouses require more economical and shorter decontamination processes. In the current study, among the various decontamination solutions, the most effective chemical solution was $3 \%$ LEV. The effect of the ozone solution application on $S$. Typhimurium was detected a lower logarithmic reduction compared to the other groups.

In conclusion, chemical decontamination agents used for decontamination of broiler carcasses should not cause residues, color and taste changes, or unwanted odor formation. To prevent such adverse effects, appropriate concentrations and application times should be used. In comparison with ozone, LEV has advantages, such as ease of use and no need for expensive instrument equipment. Considering the observed decontamination effect of LEV on chicken carcasses in the present study. LEV could be used as an alternative to ozone for decontamination of broiler carcasses.

\section{Acknowledgements}

This study was supported by the Burdur Mehmet Akif Ersoy University Scientific Research Projects Committee (project number: 0429-YL-17).

\section{References}

Abbassi-Ghozzi, I., Jaouani, A., Hammami, S., Martinez-Urtaza, J., Boudabous, A., \& Gtari, M. (2012). Molecular analysis and antimicrobial resistance of Salmonella isolates recovered from raw meat marketed in the area of "Grand Tunis", Tunisia. Pathologie Biologie, 60(5), 49-54. http://dx.doi.org/10.1016/j.patbio.2011.07.005. PMid:21856095.

Abd-Elghany, S. M., Sallam, K. I., Abd-Elkhalek, A., \& Tamura, T. (2015). Occurrence, genetic characterization and antimicrobial resistance of Salmonella isolated from chicken meat and giblets. Epidemiology and Infection, 143(5), 997-1003. http://dx.doi. org/10.1017/S0950268814001708. PMid:25004116.

Alakomi, H. L., Skyttä, E., Saarela, M., Mattila-Sandholm, T., LatvaKala, K., \& Helander, I. M. (2000). Lactic acid permeabilizes gram-negative bacteria by disrupting the outer membrane. Applied and Environmental Microbiology, 66(5), 2001-2005. http://dx.doi. org/10.1128/AEM.66.5.2001-2005.2000. PMid:10788373.

Andrews, W. H., Wang, H., Jacobson, A., \& Hammack, T. (2019). Salmonella. In Food and Drug Administration. Bacteriological Analytical Manual (BAM). Rome, Italy: FAO. Retrieved from: 
https://www.fda.gov/food/laboratory-methods-food/bacteriologicalanalytical-manual-bam-chapter-5-salmonella

Antunes, P., Mourão, J., Campos, J., \& Peixe, L. (2016). Salmonellosis: the role of poultry meat. Clinical Microbiology and Infection, 22(2), 110-121. http://dx.doi.org/10.1016/j.cmi.2015.12.004. PMid:26708671.

Bailey, J. S., Thomson, J. E., Cox, N. A., \& Shackelford, A. D. (1986). Chlorine spray washing to reduce bacterial contamination of poultry processing equipment. Poultry Science, 65(6), 1120-1123. http:// dx.doi.org/10.3382/ps.0651120.

Barbosa-Canovas, G. V., Schaffner, D. W., Pierson, M. D., \& Zhang, Q. H. (2000). Pulsed X-rays. Journal of Food Science Supplement, 65(8), 96-97. http://dx.doi.org/10.1111/j.1750-3841.2000.tb00625.x.

Barroeta, A. C. (2007). Nutritive value of poultry meat: relationship between vitamin E and PUFA. World's Poultry Science Journal, 63(2), 277-284. http://dx.doi.org/10.1017/S0043933907001468.

Bautista, D. A., Sylvester, N., Barbut, S., \& Griffiths, M. W. (1997). The determination of efficacy of antimicrobial rinses on turkey carcasses using response surface designs. International Journal of Food Microbiology, 34(3), 279-292. http://dx.doi.org/10.1016/ S0168-1605(96)01201-9. PMid:9039573.

Cetin, B., Uran, H., \& Konak, M. (2019). Effect of evaporated ethyl pyruvate on reducing Salmonella Enteritidis in raw chicken meat. Brazilian Journal of Poultry Science, 21(2), 1-8. http://dx.doi. org/10.1590/1806-9061-2018-0781.

Chavez-Martinez, A., Paredes-Montoya, P., Renteria-Monterrubio, A. L., Corral-Luna, A., Lechuga-Valles, R., Dominguez-Viveros, J., Sánchez-Vega, R., \& Santellano-Estrada, E. (2019). Microbial quality and prevalence of foodborne pathogens of cheeses commercialized at different retail points in Mexico. Food Science and Technology, 39(Suppl. 2), 703-710. http://dx.doi.org/10.1590/fst.30618.

Cho, Y., Choi, J. H., Hahn, T. W., \& Lee, S. K. (2015). Bacterial counts and oxidative properties of chicken breast inoculated with Salmonella Typhimurium exposed to gaseous ozone. Journal of Food Safety, 35(1), 137-144. http://dx.doi.org/10.1111/jfs.12161.

Cruz, M. R. G., Leite, Y. J. B. S., Marques, J. L., Pavelquesi, S. L. S., Oliveira, L. R. A., Silva, I. C. R., \& Orsi, D. C. (2019). Microbiological quality of minimally processed vegetables commercialized in Brasilia, DF, Brazil. Food Science and Technology, 39(Suppl. 2), 408-503. http:// dx.doi.org/10.1590/fst.16018.

Cunha-Neto, A., Carvalho, L. A., Castro, V. S., Barcelos, F. G., Carvalho, R. C. T., Rodrigues, D. D. P., Conte-Junior, C. A., \& Figueiredo, E. E. D. S. (2019). Salmonella Anatum, S. Infantis and S. Schwarzengrund in Brazilian Cheeses: occurrence and antibiotic resistance profiles. International Journal of Dairy Technology, 73(1), 296-300. http:// dx.doi.org/10.1111/1471-0307.12636.

Datta, A. K., \& Davidson, P. M. (2000). Microwave and radio frequency processing. Journal of Food Science, 65, 32-41. http://dx.doi. org/10.1111/j.1750-3841.2000.tb00616.x.

Del Río, E., Panizo-Morán, M., Prieto, M., Alonso-Calleja, C., \& Capita, R. (2007). Effect of various chemical decontamination treatments on natural microflora and sensory characteristics of poultry. International Journal of Food Microbiology, 115(3), 268-280. http:// dx.doi.org/10.1016/j.ijfoodmicro.2006.10.048. PMid:17320231.

Dickson, J. S., \& Anderson, M. E. (1992). Microbiological decontamination of food animal carcasses by washing and sanitizing systems: a review. Journal of Food Protection, 55(2), 133-140. http://dx.doi. org/10.4315/0362-028X-55.2.133. PMid:31071772.

Dorsa, W. J., Cutter, C. N., Siragusa, G. R., \& Koohmaraie, M. (1996). Microbial decontamination of beef and sheep carcasses by steam, hot water spray washes, and a steam-vacuum sanitizer. Journal of
Food Protection, 59(2), 127-135. http://dx.doi.org/10.4315/0362028X-59.2.127. PMid:31159001.

Durak, M. Z., Churey, J. J., Gates, M., Sacks, G. L., \& Worobo, R. W. (2012). Decontamination of green onions and baby spinach by vaporized ethyl pyruvate. Journal of Food Protection, 75(6), 1012-1022. http://dx.doi.org/10.4315/0362-028X.JFP-12-008. PMid:22691467.

El-Aziz, D. M. A. (2013). Detection of Salmonella Typhimurium in retail chicken meat and chicken giblets. Asian Pacific Journal of Tropical Biomedicine, 3(9), 678-681. http://dx.doi.org/10.1016/ S2221-1691(13)60138-0. PMid:23998006.

Eng, S. K., Pusparajah, P., Ab Mutalib, N. S., Ser, H. L., Chan, K. G., \& Lee, L. H. (2015). Salmonella: a review on pathogenesis, epidemiology and antibiotic resistance. Frontiers in Life Science, 8(3), 284-293. http://dx.doi.org/10.1080/21553769.2015.1051243.

Fabrizio, K. A., Sharma, R. R., Demirci, A., \& Cutter, C. N. (2002). Comparison of electrolyzed oxidizing water with various antimicrobial interventions to reduce Salmonella species on poultry. Poultry Science, 81(10), 1598-1605. http://dx.doi.org/10.1093/ps/81.10.1598. PMid:12412930.

Farkas, J. (1998). Irradiation as a method for decontaminating food: a review. International Journal of Food Microbiology, 44(3), 189-204. http://dx.doi.org/10.1016/S0168-1605(98)00132-9. PMid:9851599.

Farrell, D. (2013). The role of poultry in human nutrition. In Food and Agriculture Organization of the United Nations. Poultry Development Review. Rome, Italy: FAO. Retrieved from http://www.fao.org/3/ al709e/al709e00.pdf.

Freitas, C. G., Santana, Â. P., Silva, P. H. C., Gonçalves, V. S. P., Barros, M. D. A. F., Torres, F. A. G., Murata, L. S., \& Perecmanis, S. (2010). PCR multiplex for detection of Salmonella Enteritidis, Typhi and Typhimurium and occurrence in poultry meat. International Journal of Food Microbiology, 139(1-2), 15-22. http://dx.doi.org/10.1016/j. ijfoodmicro.2010.02.007. PMid:20199820.

Givens, D. I., Kliem, K. E., \& Gibbs, R. A. (2006). The role of meat as a source of $\mathrm{n}-3$ polyunsaturated fatty acids in the human diet. Meat Science, 74(1), 209-218. http://dx.doi.org/10.1016/j. meatsci.2006.04.008. PMid:22062730.

Goncuoglu, M., Ormanci, F. S. B., Uludag, M., \& Cil, G. I. (2016). Prevalence and antibiotic resistance of Salmonella spp. and Salmonella Typhimurium in broiler carcasses wings and liver. Journal of Food Safety, 36(4), 524-531. http://dx.doi.org/10.1111/jfs.12272.

Guzel-Seydim, Z. B., Greene, A. K., \& Seydim, A. C. (2004). Use of ozone in the food industry. Lebensmittel-Wissenschaft + Technologie, 37(4), 453-460. http://dx.doi.org/10.1016/j.lwt.2003.10.014.

Helander, I., von Wright, A., \& Mattila-Sandholm, T. M. (1997). Potential of lactic acid bacteria and novel antimicrobials against Gram-negative bacteria. Trends in Food Science \& Technology, 8(5), 146-150. http:// dx.doi.org/10.1016/S0924-2244(97)01030-3.

Heredia, N., \& García, S. (2018). Animals as sources of food-borne pathogens: A review. Animal Nutrition, 4(3), 250-255. http://dx.doi. org/10.1016/j.aninu.2018.04.006. PMid:30175252.

Huffman, R. D. (2002). Current and future technologies for the decontamination of carcasses and fresh meat. Meat Science, 62(3), 285-294. http://dx.doi.org/10.1016/S0309-1740(02)00120-1. PMid:22061605.

Jia, Z., Peng, Y., Yan, X., Zhang, Z., Fang, T., \& Li, C. (2020). Onestep kinetic analysis of competitive growth of Salmonella spp. and background flora in ground chicken. Food Control, 107103. http:// dx.doi.org/10.1016/j.foodcont.2020.107103.

Kim, J. G., Yousef, A. E., \& Dave, S. (1999). Application of ozone for enhancing the microbiological safety and quality of foods: a 
review. Journal of Food Protection, 62(9), 1071-1087. http://dx.doi. org/10.4315/0362-028X-62.9.1071. PMid:10492485.

Lillard, H. S. (1994). Effect of trisodium phosphate on salmonellae attached to chicken skin. Journal of Food Protection, 57(6), 465-469. http://dx.doi.org/10.4315/0362-028X-57.6.465. PMid:31121663.

Madushanka, D. N. N., Jayaweera, T. S. P., Jayasinghe, J. M. C. S., Yasawathie, D. G., \& Ruwandeepika, H. A. D. (2018). Decontaminating effect of organic acids and natural compounds on broiler chicken meat contaminated with Salmonella Typhimurium. Asian Food Science Journal, 3(1), 1-9. http://dx.doi.org/10.9734/AFSJ/2018/41802.

Mani-López, E., García, H. S., \& López-Malo, A. (2012). Organic acids as antimicrobials to control Salmonella in meat and poultry products. Food Research International, 45(2), 713-721. http://dx.doi. org/10.1016/j.foodres.2011.04.043.

Manoj, J., Singh, M. K., \& Singh, Y. P. (2015). The role of poultry in food borne salmonellosis and its public health importance. Advances in Animal and Veterinary Sciences, 3(9), 485-490. http://dx.doi. org/10.14737/journal.aavs/2015/3.9.485.490.

Meireles, A., Giaouris, E., \& Simões, M. (2016). Alternative disinfection methods to chlorine for use in the fresh-cut industry. Food Research International, 82, 71-85. http://dx.doi.org/10.1016/j.foodres.2016.01.021.

Mendonça, J. F. M., Vieira, F. O., Fonseca, I., Ribeiro, J. B., Arcuri, E. F., Borges, M. F., Borges, C. A. V., Sá, J. F. O., \& Martins, M. F. (2019). Detection of Viable Salmonella Typhimurium and Staphylococcus aureus in Coalho Cheese by Real-Time PCR. Food Science and Technology, 39(Suppl. 2), 690-696. http://dx.doi.org/10.1590/fst.29318.

Mohamed, H. M., \& Abdel-Naeem, H. H. (2018). Enhancing the bactericidal efficacy of lactic acid against Salmonella Typhimurium attached to chicken skin by sodium dodecyl sulphate addition. Lebensmittel-Wissenschaft + Technologie, 87, 464-469. http://dx.doi. org/10.1016/j.lwt.2017.09.022.

Mulder, R. W. A. W., Van der Hulst, M. C., \& Bolder, N. M. (1987). Research note: Salmonella decontamination of broiler carcasses with lactic acid, L-cysteine, and hydrogen peroxide. Poultry Science, 66(9), 1555-1557. http://dx.doi.org/10.3382/ps.0661555. PMid:3317366.

Oliveira, T. S., Varjão, L. M., Silva, L. N. N., Pereira, R. D. C. L., Hofer, E., Vallim, D. C., \& Castro Almeida, R. C. (2018). Listeria monocytogenes at chicken slaughterhouse: Occurrence, genetic relationship among isolates and evaluation of antimicrobial susceptibility. Food Control, 88, 131-138. http://dx.doi.org/10.1016/j.foodcont.2018.01.015.

Park, C. M., Hung, Y. C., Doyle, M. P., Ezeike, G. O. I., \& Kim, C. (2001). Pathogen reduction and quality of lettuce treated with electrolyzed oxidizing and acidified chlorinated water. Journal of Food Science, 66(9), 1368-1372. http://dx.doi.org/10.1111/j.1365-2621.2001.tb15216.x.

Park, S. Y., Mizan, M. F. R., \& Ha, S. D. (2016). Inactivation of Cronobacter sakazakii in head lettuce by using a combination of ultrasound and sodium hypochlorite. Food Control, 60, 582-587. http://dx.doi. org/10.1016/j.foodcont.2015.08.041.

Pereira, P. M. D. C. C., \& Vicente, A. F. D. R. B. (2013). Meat nutritional composition and nutritive role in the human diet. Meat Science, 93(3), 586-592. http://dx.doi.org/10.1016/j.meatsci.2012.09.018. PMid:23273468.

Portela, J. B., Coimbra, P. T., Cappato, L. P., Alvarenga, V. O., Oliveira, R. B., Pereira, K. S., Azeredo, D. R. P., Sant'Ana, A. S., Nascimento, J. S., \& Cruz, A. G. (2019). Predictive model for inactivation of Salmonella in infant formula during microwave heating processing. Food Control, 104, 308-312. http://dx.doi.org/10.1016/j.foodcont.2019.05.006.

Pothakamury, U. R., Barbosa-Cánovas, G. V., \& Swanson, B. G. (1993). Magnetic-field inactivation of microorganisms and generation of biological changes. Food Technology, 47(12), 85-93.
Ren, D., Chen, P., Wang, Y., Wang, J., Liu, H., \& Liu, H. (2017). Phenotypes and antimicrobial resistance genes in Salmonella isolated from retail chicken and pork in Changchun, China. Journal of Food Safety, 37(2), e12314. http://dx.doi.org/10.1111/jfs.12314.

Rouger, A., Tresse, O., \& Zagorec, M. (2017). Bacterial contaminants of poultry meat: Sources, species, and dynamics. Microorganisms, 5(3), 50. http://dx.doi.org/10.3390/microorganisms5030050. PMid:28841156.

Sánchez-Gamboa, C., Hicks-Pérez, L., Gutiérrez-Méndez, N., Heredia, N., García, S., \& Nevárez-Moorillón, G. V. (2018). Seasonal influence on the microbial profile of Chihuahua cheese manufactured from raw milk. International Journal of Dairy Technology, 71, 81-89. http:// dx.doi.org/10.1111/1471-0307.12423.

Sastry, S. K., Datta, A. K., \& Worobo, R. W. (2000). Ultraviolet light. Journal of Food Science-Supplement, 65(8), 90-92. http://dx.doi. org/10.1111/j.1750-3841.2000.tb00623.x.

Sharma, J., Kumar, D., Hussain, S., Pathak, A., Shukla, M., Kumar, V. P., Anisha, P. N., Rautela, R., Upadhyay, A. K., \& Singh, S. P. (2019). Prevalence, antimicrobial resistance and virulence genes characterization of nontyphoidal Salmonella isolated from retail chicken meat shops in Northern India. Food Control, 102, 104-111. http://dx.doi.org/10.1016/j.foodcont.2019.01.021.

Slavik, M. F., Walker, J. T., \& Xiong, H. (1997). Pre-chill spray of chicken carcasses to reduce Salmonella Typhimurium. Journal of Food Science, 62(3), 605-607. http://dx.doi.org/10.1111/j.1365-2621.1997.tb04441.x.

Sofos, J. N., \& Smith, G. C. (1998). Nonacid meat decontamination technologies: Model studies and commercial applications. International Journal of Food Microbiology, 44(3), 171-188. http://dx.doi.org/10.1016/ S0168-1605(98)00136-6. PMid:9851598.

Thung, T. Y., Mahyudin, N. A., Basri, D. F., Wan Mohamed Radzi, C. W. J., Nakaguchi, Y., Nishibuchi, M., \& Radu, S. (2016). Prevalence and antibiotic resistance of Salmonella Enteritidis and Salmonella Typhimurium in raw chicken meat at retail markets in Malaysia. Poultry Science, 95(8), 1888-1893. http://dx.doi.org/10.3382/ps/ pew144. PMid:27118863.

Trongjit, S., Angkititrakul, S., Tuttle, R. E., Poungseree, J., Padungtod, P., \& Chuanchuen, R. (2017). Prevalence and antimicrobial resistance in Salmonella enterica isolated from broiler chickens, pigs and meat products in Thailand-Cambodia border provinces. Microbiology and Immunology, 61(1), 23-33. http://dx.doi.org/10.1111/13480421.12462. PMid:28042666.

van Nierop, W., Duse, A. G., Marais, E., Aithma, N., Thothobolo, N., Kassel, M., Stewart, R., Potgieter, A., Fernandes, B., Galpin, J. S., \& Bloomfield, S. F. (2005). Contamination of chicken carcasses in Gauteng, South Africa, by Salmonella, Listeria monocytogenes and Campylobacter. International Journal of Food Microbiology, 99(1), 1-6. http://dx.doi.org/10.1016/j.ijfoodmicro.2004.06.009. PMid:15718024.

Wang, H., Qi, J., Duan, D., Dong, Y., Xu, X., \& Zhou, G. (2018). Combination of a novel designed spray cabinet and electrolyzed water to reduce microorganisms on chicken carcasses. Food Control, 86, 200-206. http://dx.doi.org/10.1016/j.foodcont.2017.11.027.

Xiong, H., Li, Y., Slavik, M. F., \& Walker, J. T. (1998). Spraying chicken skin with selected chemicals to reduce attached Salmonella Typhimurium. Journal of Food Protection, 61(3), 272-275. http:// dx.doi.org/10.4315/0362-028X-61.3.272. PMid:9708294.

Xu, Q., Yin, Y., Liu, D., Zhang, J., Wu, Q., Tian, P., Shi, X., \& Wang, D. (2018). Prevalence and characterization of Salmonella serovars isolated from farm products in Shanghai. Food Control, 85, 269-275. http://dx.doi.org/10.1016/j.foodcont.2017.10.009.

Yang, B., Qu, D., Zhang, X., Shen, J., Cui, S., Shi, Y., Xi, M., Sheng, M., Zhi, S., \& Meng, J. (2010). Prevalence and characterization of 
Salmonella serovars in retail meats of marketplace in Shaanxi, China. International Journal of Food Microbiology, 141(1-2), 63-72. http:// dx.doi.org/10.1016/j.ijfoodmicro.2010.04.015. PMid:20493570.

Yang, H., Li, Y., \& Johnson, M. G. (2001). Survival and death of Salmonella Typhimurium and Campylobacter jejuni in processing water and on chicken skin during poultry scalding and chilling. Journal of Food Protection, 64(6), 770-776. http://dx.doi.org/10.4315/0362028X-64.6.770. PMid:11403124.

Yang, X., Wu, Q., Huang, J., Wu, S., Zhang, J., Chen, L., Wei, X., Ye, Y., Li, Y., Wang, J., Lei, T., Xue, L., Pang, R., Zhang, Y. (2020). Prevalence and characterization of Salmonella isolated from raw vegetables in China. Food Control. http://dx.doi.org/10.1016/j.foodcont.2019.106915.

Zhang, Q., Chang, F. J., Barbosa-Cánovas, G. V., \& Swanson, B. G. (1994). Inactivation of microorganisms in a semisolid model food using high voltage pulsed electric fields. Lebensmittel-Wissenschaft + Technologie, 27(6), 538-543. http://dx.doi.org/10.1006/fstl.1994.1106.

Zhao, T., Zhao, P., \& Doyle, M. P. (2009). Inactivation of Salmonella and Escherichia coli O157: H7 on lettuce and poultry skin by combinations of levulinic acid and sodium dodecyl sulfate. Journal of Food Protection, 72(5), 928-936. http://dx.doi.org/10.4315/0362028X-72.5.928. PMid:19517717.

Zhao, T., Zhao, P., Cannon, J. L., \& Doyle, M. P. (2011). Inactivation of Salmonella in biofilms and on chicken cages and preharvest poultry by levulinic acid and sodium dodecyl sulfate. Journal of Food Protection, 74(12), 2024-2030. http://dx.doi.org/10.4315/0362-028X. JFP-11-197. PMid:22186041.

Zhu, J., Yao, B., Song, X., Wang, Y., Cui, S., Xu, H., Yang, B., Huang, J., Liu, G., Yang, X., Gong, P., Chen, Q., \& Li, F. (2017). Prevalence and quantification of Campylobacter contamination on raw chicken carcasses for retail sale in China. Food Control, 75, 196-202. http:// dx.doi.org/10.1016/j.foodcont.2016.12.007.

Zwe, Y. H., Tang, V. C. Y., Aung, K. T., Gutiérrez, R. A., Ng, L. C., \& Yuk, H. G. (2018). Prevalence, sequence types, antibiotic resistance and, gyrA mutations of Salmonella isolated from retail fresh chicken meat in Singapore. Food Control, 90, 233-240. http://dx.doi.org/10.1016/j. foodcont.2018.03.004. 